\title{
UM NOVO SÍTIO NA INTERNET, DEDICADO A ORLANDO RIBEIRO
}

SuZANNe Daveau ${ }^{1}$

Acaba de ser divulgado na Internet o Sítio http://www.orlando-ribeiro.info/, que reúne abundante informação sobre o geógrafo. Resulta do projecto de investigação desenvolvido para o tratamento e disponibilização da sua Biblioteca científica pessoal, legada por ele, em 1983, ao Centro de Estudos Geográficos de Lisboa, com os outros elementos do seu vasto espólio científico. A construção do Sítio foi realizado pela Bookmarc, sob a coordenação esclarecida de Maria Inês Cordeiro.

Sobre o legado e o subsequente Projecto financiado, em 2001, pela Fundação para a Ciência e Tecnologia, remete-se para as informações contidas na nota incluída no número 73 da Finisterra (2002: 133-137). Ao longo do ano passado, o trabalho foi prosseguindo a bom ritmo, graças ao impulso e excelente coordenação técnica de Joaquina Feijão e ao apoio financeiro da Fundação Calouste Gulbenkian.

O Sítio agora tornado acessível ao público, pode ser consultado em três línguas: português, francês et inglês. Inclui um Catálogo online, referente à maior parte da Biblioteca científica pessoal de Orlando Ribeiro (já com cerca de 8.500 referências e a ser completado nos próximos meses). Este Catálogo tem a interessante particularidade de incluir imagens das numerosas dedicatórias existentes nas separatas e livros, as quais ajudam a entender os tipos de relações científicas e humanas que ligavam Orlando Ribeiro aos seus contemporâneos.

Além deste Catálogo, fruto do Projecto de investigação acima mencionado, o Sítio apresenta também uma série de outras rubricas informativas, entre as quais a Bibliografia exaustiva das obras do autor (mais de 400 referências, que podem ser também consultadas e reproduzidas em $p d f$ ) e uma selecção dos títulos mais significativos dos artigos que foram, até hoje, consagrados à sua vida e obra.

Encontra-se ainda no Sítio a Apresentação bio-bibliográfica do geógrafo, organizada cronologicamente pelos grandes períodos da sua vida e ilustrada com numerosas imagens, tiradas do seu espólio pessoal ou devidas ao fotógrafo Duarte Belo.

Aproveitou-se a selecção das Fotografias do próprio Orlando Ribeiro, arquivadas no Centro de Estudos Geográficos, que foi realizada em 2002 por Mário Neves para a exposição Além-Mar, Viagens de Orlando Ribeiro. Parte desta selecção encontra-se agora divulgada no Sítio, evocando as numerosas viagens realizadas através do Mundo pelo geógrafo, para as várias terras então dependentes de Portugal.

1 Investigadora do Centro de Estudos Geográficos, Univ. de Lisboa. E-mail:sdaveau@clix.pt 
O Sitio desvenda igualmente, e pela primeira vez, o rico arquivo científico dos cerca de 60 Cadernos de campo, que Orlando Ribeiro preencheu ao longo de uma vida de intensa investigação no terreno, em mais de meio século. A lista dos Cadernos é acompanhada por uma selecção de páginas representativas dos tipos de notas e reflexões, desenhos e lembranças, que foi acumulando neles ao correr todo Portugal e muitos outros países. A divulgação do conteúdo dos Cadernos de campo exigirá ainda um grande esforço de tratamento, o qual se encontra já em curso, numa primeira fase de decifração e indexação.

As numerosas pessoas, familiares, colegas, discípulos e técnicos, que colaboraram na realização deste Sítio e das quais algumas apenas foram mencionadas acima, vão prosseguindo o seu cuidadoso trabalho, com vista a melhorá-lo e completá-lo durante os próximos meses. Esperamos ter já realizado e difundido um instrumento de trabalho cómodo e útil, posto à disposição das gerações actuais e futuras, que permita um acesso facilitado a uma obra vasta e original, de forte e diversificada relevância na cultura portuguesa do século XX. 